\title{
TEACHERS' COMPUTER SELF-EFFICACY AND THEIR USE OF EDUCATIONAL TECHNOLOGY
}

\section{ABSTRACT}

\author{
Vehbi TUREL \\ Vocational Higher School, \\ Computer Programming \\ The University of Bingol, TURKEY
}

This study examined the use of educational technology by primary and subject teachers (i.e. secondary and high school teachers) in a small town in the eastern part of Turkey in the spring of 2012. The study examined the primary, secondary and high school teachers'
$>$ personal and computer related (demographic) characteristics,
$>$ their computer self-efficacy perceptions,
$>$ their computer-using level in certain software,
$>$ their frequency of computer use for teaching, administrative and communication objectives, and
$>$ their use of educational technology preferences for preparation and teaching purposes.

In this study, all primary, secondary and high school teachers in the small town were given the questionnaires to complete. 158 teachers $(n=158)$ completed and returned them. The study was mostly quantitative and partly qualitative. The quantitative results were analysed with SPSS (i.e. mean, Std. Deviation, frequency, percentage, ANOVA). The qualitative data were analysed with examining the participants' responses gathered from the open-ended questions and focussing on the shared themes among the responses.

The results reveal that the teachers think that they have good computer self-efficacy perceptions, their level in certain programs is good, and they often use computers for a wide range of purposes. There are also statistical differences between;

$>$ their computer self-efficacy perceptions,

$>$ frequency of computer use for certain purposes, and

$>$ computer level in certain programs in terms of different independent variables.

Keywords: Teachers; educational technology; information and communication technology (ICT); primary, secondary and high schools; computer selfefficacy perceptions. 


\section{INTRODUCTION}

Educational technology is in a wide range of diverse forms such as programs, databases; the Internet, intranet, e-mail; video, overhead projectors, computer projectors, scanners, cassette players, interactive whiteboards or any type of digital resources.

To this end, different studies on different characteristics of education technology such as the use of digital resources (Maher et al. 2012), the use of interactive whiteboards (Türel \& Johnson, 2012), the difficulties teaching staff/teachers face with in using educational technology (Türel 2013; Buchanan et al. 2013; Usluel-Koçak \& Seferoglu 2004), the design of digital materials (Türel 2014; Turel \& McKenna 2013; Turel 2012, 2011, 2010), human-educational technology interaction and health (Bilge 2012; Altun \& Cakan 2006; Keser 2005; Odabası 2005; Ozden et al. 2004) and so forth were conducted.

Teachers have used educational technology for teaching/learning since the use of computers, the Internet and digital resources in classrooms. Teachers have used computers and the Internet at primary, secondary and high schools in Turkey in the last $\mathbf{1 5}$ years although it is still very limited in many parts of Turkey. The use of educational technology by teachers in some other countries goes further back (Romeo 2006). For example, Teachers have used ICT (i.e. digital resources, the Internet, computer projectors, interactive whiteboards) at primary and secondary schools in England since 1995. Tremendous investment and effort were made in some countries to make use of educational technology more widely and efficiently (Romeo et al. 2012; Balasubramanian et.al. 2009; Becta 2009).

The use, the efficient use and the frequency use of educational technology by teachers at primary, secondary and high schools can show significant differences not only among different countries (Maher et al. 2012; Yeung 2012; Kregor et al. 2012; Kennedy et al. 2009), but also among different schools in the same country. It can be claimed that nowadays teachers use educational technology at all primary, secondary and high schools in all developed countries and at many schools in developing countries.

Even more and more teachers begin to use educational technology to deliver teaching at primary, secondary and high schools (Hong and Lai 2011). In fact, teachers at primary, secondary and high schools no longer have a choice whether to use educational technology or not, they have to use it in order to be competitive in this age.

Moreover, today's primary, secondary and high schools pupils and students, who are in general digitally fluent and competitive to some extent, expect educational technology to be used more widely in teaching and learning. Therefore, teachers at primary, secondary and high schools should respond to such learning demands and differences to accommodate the digital-literate, wise and efficient learning style preferences (DuncanHowell 2012; Prensky 2001). 
Although the use of educational technology by teachers at primary, secondary and high schools is important, the use of the right digital resources and their efficient use are more vital. Only physically having educational technology or solely using educational technology at primary, secondary and high schools in itself is no longer enough. Teachers have to use educational technology selectively, efficiently and effectively. For example, Yanpar (2011) emphasizes that the selection of the right and effective digital resources is an essential part of efficient teaching and learning.

The successful use of educational technology at primary, secondary and high schools is fully in the hands of the teachers. If teachers use educational technology efficiently as a tool, then they are more likely to enable pupils and students to achieve the targeted objectives, which are to gain the required literacy, numeracy, communication, learning how to learn and ICT skills. Then, it can be said that teachers use educational technology in true-sense.Although teachers have been using computers and the internet at primary, secondary and high schools in certain parts of Turkey for the last $\mathbf{1 5}$ years; it is not known to what extent the teachers in a small town in the eastern part of the country have computer self-efficacy perceptions as well as have been taking the advantage of the potential benefits that educational technology can afford at primary, secondary and high schools. Therefore, five major research questions were investigated:

$>$ How do the teachers in a small town in the eastern part of Turkey perceive their general self-efficacy in regard to the use of computers?

$>$ What is their level in using certain software?

$>$ How often do they use computers for teaching, administrative and communication?

$>$ What are their educational technology preferences for preparation and teaching purposes?

$>$ Are their certain perceptions associated with their:

- (place of) computer access,

- computer using period and

- the frequency of computer use?

\section{THE STUDY}

\section{The Aim of the Study}

Such similar studies were conducted before (Türel 2013; Kucuk et al., 2013; Goktas et al., 2012; Usluel-Koçak \& Seferoğlu, 2004). This research focuses on the "teachers working at the schools in a small town in the eastern part of Turkey". Therefore, this study could provide some valuable information. Most of such studies were conducted in big cities (Istanbul, Ankara, etc.). On the other hand, to this end, teachers working at schools in the eastern part of Turkey have not been investigated in detail yet. Thus, in terms of this point of view, this study can be said as significant to contribute.

This study gathered empirical data to find out 158 teachers'; 
$>$ demographic characteristics,

$>$ their computer self-efficacy beliefs,

$>$ their computer-using level in certain programs,

$>$ their frequency of computer use for teaching, administrative and communication purposes,

$>$ their use of technology preferences for preparation and teaching purposes

$>$ whether there is any association between their perceptions and certain independent variables, as indicated above.

\section{The Participants}

The participants were $158(\mathrm{~N}=158)$ full-time permanent primary, secondary and high schools teachers $(67.1 \%$ male, $32.9 \%$ female) in a small town in the eastern part of Turkey. The potential participant pool was approximately 474 . The participants represented a response rate of $33.33 \%$. $24.1 \%$ were primary school teachers, $25.9 \%$ were secondary school teachers, $48.7 \%$ were high school teachers, $0.6 \%$ was teaching both at secondary and high schools and $0.6 \%$ was teaching at all three types of the schools. Their age spread varied, being 21-30 (62.0\%), 31-40 (28.5\%), 41-50 (6.3\%), and 51-60 (2.5\%). According to the teachers' personal and computer related characteristics questionnaire, $24.1 \%$ have access to computers at home. $15.8 \%$ have access to computers at school. $60.1 \%$ have access to computers both at home and school. The teachers learnt how to use computers in a wide range of ways: by themselves $(55 \%)$, at work $(3.2 \%)$, at a private course $(18.4 \%)$, at an institutional course $(17.1 \%)$, or at a combination of the mentioned places $(6.3 \%)$.

Table: 1

The Teachers' Use of Computer Purposes

\begin{tabular}{l|c|c}
\multicolumn{1}{c|}{$\begin{array}{c}\text { Items } \\
\text { For which purposes do the teachers use computers? }\end{array}$} & F \\
\hline Communication, Internet, Teaching/Learning & 48 & 30.4 \\
\hline Communication, Teaching/Learning & 35 & 22.2 \\
\hline Teaching/Learning & 20 & 12.7 \\
\hline All & 13 & 8.2 \\
\hline Communication & 9 & 5.7 \\
\hline Teaching/Learning, Others & 8 & 5.1 \\
\hline Others & 6 & 3.8 \\
\hline Communication, Internet & 4 & 2.5 \\
\hline Internet, Teaching/Learning, Others & 4 & 2.5 \\
\hline Internet & 3 & 1.9 \\
\hline Internet, Teaching/Learning & 2 & 1.3 \\
\hline No-answer & 2 & 2.4 \\
\hline Total & 2 & 1.3 \\
\hline
\end{tabular}


In terms of how long the teachers used information and communication technology (ICT), and the results were ranked as follow: 1-5 years $(19.6 \%), 6-10(55.1 \%), 11-15$ $(22.8 \%)$, and 16 and above years (2.5\%). In terms of how often they use ICT, the results were: very often every day $(27.2 \%)$, a few hours every day $(51.3 \%)$, a few days weekly $(12.7 \%)$ and a few hours or less weekly $(8.8 \%)$. This shows that the teachers self-rated themselves to be regular users of ICT. When the teachers were asked for which purposes they used computers (they could choose more than one option), $30.4 \%$ stated that they used computers for 'communication + internet + teaching/learning' (Table 1). $22.2 \%$ used computers for 'communication + teaching/learning', $12.7 \%$ used computers only for teaching/learning. All over, around $95 \%$ revealed that they used computers for 'communication + internet + teaching/learning'.

\section{METHODOLOGY}

The current study was mostly quantitative and partly qualitative. In order to be able to use data collection tools consistent with the purpose of the current study, the relevant present studies were examined (Maher et al. 2012; Askar and Umay 2001; Turel and Johnson, 2012; Usluel-Koçak and Seferoglu 2004; Albion 2001; Bandura 1997). Consequently, some of the existing questionnaires and open-ended questions were made use of and some new ones were further added. The teachers' personal and computer related characteristics questionnaire was designed and created by the researchers. It consisted of 11 diverse items. It aimed to collect broad demographic information. The source of the teachers' computer self-efficacy perceptions questionnaire was Askar and Umay's data collecting procedures (2001).

The questionnaire $(a=.896)$ included 18 Likert scale items from never to always (items 118). The teachers' computer-using level in certain programs questionnaire (items 19-28) and their frequency of computer use for teaching, administrative and communication purposes questionnaire (items 29-34, $a=.786$ ) were taken from Usluel-Koçak and Seferoglu (2004). The former $(a=.914)$ included 10 Likert scale items from very poor to advanced and the latter $(a=.786)$ included 6 Likert scale items from never to always. The source of the teachers' use of technology preferences for preparation and teaching purposes questionnaire was Türel's data collecting procedures for the same purpose (2013).

It consisted of two diverse items. The teachers were also requested to answer three open-ended questions, which aimed to further support the quantitative data.

\section{FINDINGS}

The findings are presented in five parts, corresponding to the above mentioned five research questions. The quantitative data was analysed with SPSS (i.e. mean, Std. Deviation, frequency, percentage, ANOVA). The qualitative data was analysed by examining the teachers' responses gathered from the three open-ended questions. It focused on the shared themes among the teachers' responses. 
Teachers' Computer Self-efficacy Perceptions

The analysed results revealed that that the teachers' computer self-efficacy perceptions were positive (Table 2). The teachers believe that they:

$>$ have a special gift towards the use of computers $(M=2.71)$,

$>$ are skilled at computing $(M=2.94)$,

$>$ feel confident in using computers $(M=3.15)$,

$>$ can solve computer related problems if they try hard $(M=3.39)$,

$>$ know what to do on a computer when they encounter a problem $(M=2.92)$,

$>$ believe that it is easy for them to use a computer for all genres of writing $(M=3.25)$.

Table: 2

The Teachers' Computer Self-efficacy Perceptions

\begin{tabular}{|c|c|c|c|c|}
\hline \multicolumn{2}{|r|}{ Items } & \multirow{2}{*}{$\begin{array}{c}\mathbf{N} \\
156 \\
\end{array}$} & \multirow{2}{*}{$\begin{array}{c}\text { Mean } \\
2.71 \\
\end{array}$} & \multirow{2}{*}{$\frac{\text { Std. Dev }}{1.107}$} \\
\hline 1 & I believe that I have a special gift towards the use ofcomputers & & & \\
\hline 2 & I am skilled at computing & 158 & 2.94 & .949 \\
\hline 3 & I feel confident in using computers & 156 & 3.15 & .907 \\
\hline 4 & If I try hard enough I can solve computer related problems & 158 & 3.39 & 1.087 \\
\hline 5 & I know what to do on a computer when I encounter a problem & 157 & 2.92 & .980 \\
\hline \multirow[t]{2}{*}{6} & It is easy for me to use a computer for all genres of writing & 154 & 3.25 & 1.051 \\
\hline & Sometimes 3 & Often 4 & \multicolumn{2}{|c|}{ Always 5} \\
\hline 7 & I have the fear of making mistakes whilst using computers & 156 & 4.49 & .823 \\
\hline 8 & I believe that it is impossible for me to fully master computing & 157 & 4.20 & 1.059 \\
\hline 9 & I'm nervous about working on computers & 158 & 4.34 & .943 \\
\hline \multirow[t]{2}{*}{10} & I encounter problems with computers whilst doing work them & 156 & 4.02 & .766 \\
\hline & Sometimes 3 & \multicolumn{2}{|c|}{ Seldom 4} & Never 5 \\
\hline 11 & $\begin{array}{l}\text { When working on computers, quick solutions to problems are } \\
\text { enough for me }\end{array}$ & 157 & 2.86 & .997 \\
\hline 12 & I believe that I fully know computer terms and concepts & 156 & 2.97 & .973 \\
\hline 13 & Using computers plays a big part in my life & 153 & 2.23 & 1.144 \\
\hline 14 & I use a computer to plan my time & 156 & 2.29 & 1.079 \\
\hline 15 & I discover new things on the computer & 157 & 2.79 & 1.032 \\
\hline \multirow[t]{2}{*}{16} & I think I can use the computer efficiently & 157 & 3.19 & 1.007 \\
\hline & Sometimes 3 & Often 4 & \multicolumn{2}{|c|}{ Always 5} \\
\hline 17 & $\begin{array}{l}\text { I get nervous when I suddenly } \\
\text { encounter problems on the computer }\end{array}$ & 156 & 4.03 & .929 \\
\hline \multirow[t]{2}{*}{18} & Most of the time I spend on a computer is unnecessary & 156 & & .994 \\
\hline & Sometimes 3 & & \multicolumn{2}{|c|}{ Never 5} \\
\hline
\end{tabular}

When the teachers were asked the negative statements about their computer selfefficacy perceptions, the results revealed that the teachers' computer self-efficacy perceptions were very positive. The teachers do not have the fear of making mistakes while using computers $(M=4.49)$. They believe that it is possible for them to fully master computing $(M=4.20)$. They are not nervous about working on computers $(M=4.34)$. 
They do not encounter problems with computers whist doing work on them $(M=4.02)$. In the same way, the teachers do not get nervous when they suddenly encounter problems on the computer $(M=4.03)$ and they think that most of the time they spend on a computer is necessary $(M=3.78)$. They believe that they fully know computer terms and concepts $(M=2.97)$ and can use computer efficiently $(M=3.19)$. They also think that when working on computers, quick solutions to problems are enough for them $(M=2.86)$ and they discover new things on the computer $(M=2.79)$. Conversely, the majority of the teachers do not think that computer plays a big part in their life $(M=2.23)$ and do not use computer to plan their time $(M=2.29)$.

\section{Teachers' Level in Using Certain Software}

The results in Table 3 show that the teachers are very good in using e-mail $(M=3.91)$ and the Internet $(M=3.88)$. They think that they are good in Word Processors (i.e. Microsoft Word) $(M=3.58)$, and Presentation Programs (i.e. Microsoft PowerPoint) $(M=3.38)$. They are average in using Statistics programs $(M=2.51)$, a program related to their area of expertise $(M=2.73)$, scanners $(M=2.73)$, Desktop publishing $(M=2.82)$, Spreadsheet (i.e. Excel) $(M=2.96)$, and are below average in using a Database Program (i.e. Microsoft Access) $(M=2.13)$.

Table: 3

The Teachers' Level in Using Certain Programs

\begin{tabular}{l|l|l|l|l}
\hline & \multicolumn{1}{|c|}{ Items } & $N$ & Mean & $\begin{array}{l}\text { Std. } \\
\text { Deviation }\end{array}$ \\
\hline 19 & What is your level in using the Word Processor (Microsoft Word)? & 151 & 3.58 & .912 \\
\hline 20 & What is your level in using the Spreadsheet (i.e. Microsoft Excel)? & 152 & 2.96 & .883 \\
\hline 21 & $\begin{array}{l}\text { What is your level in using Presentation Programs } \\
\text { (i.e. Microsoft Power Point)? }\end{array}$ & 152 & 3.38 & 1.041 \\
\hline 22 & $\begin{array}{l}\text { What is your level in using the Database Program } \\
\text { (i.e. Microsoft Access)? }\end{array}$ & 152 & 2.13 & 1.090 \\
\hline 23 & $\begin{array}{l}\text { What is your level in using e-mail } \\
\text { (i.e. Yahoo mail, Hotmail, Gmail, MS Outlook etc.)? }\end{array}$ & 152 & 3.91 & .864 \\
\hline 24 & What is your level in using the Internet / WWW? & 152 & 3.88 & .935 \\
\hline 25 & What is your level in using Statistics Programs (Excel, SPSS etc.)? & 151 & 2.51 & .965 \\
\hline 26 & What is your level in using scanners? & 147 & 2.73 & 1.184 \\
\hline 27 & $\begin{array}{l}\text { What is your level in using desktop publishing? } \\
\text { (i.e. Microsoft Publisher, Word etc.)? }\end{array}$ & 147 & 2.82 & 1.147 \\
\hline 28 & $\begin{array}{l}\text { If you are using a program related to your area of } \\
\text { expertise, what is your level in using this program? }\end{array}$ & 64 & 2.73 & 1.428 \\
\hline & Very poor 1 $\quad$ Poor $2 \quad$ Good 4 & Advanced 5 \\
\hline
\end{tabular}

Teachers' Frequency and Purpose of Computer Use

The teachers make use of computers mostly for communication (i.e. email, chat etc.) $(M=4.04)$ and for browsing the Internet $(M=3.86)$. This is followed by using computers in preparing teaching notes $(M=3.64)$, for administrative purposes $(M=3.30)$, in evaluation and measurement of students' work $(M=3.13)$ and in teaching their lessons in the class $(M=2.75)$. 
It appears that communication applications (i.e. e-mail, the internet) are the most popular and most commonly used by the teachers.

Table: 4

The Teachers' Frequency and Purpose of Computer Use

\begin{tabular}{l|l|l|l|l}
\hline \multicolumn{1}{|c|}{ Ittems } & $\mathbf{N}$ & $\begin{array}{l}\text { Mea } \\
\text { n }\end{array}$ & $\begin{array}{l}\text { Std. } \\
\text { Deviation }\end{array}$ \\
\hline $\mathbf{2 9}$ & I use computers in preparing teaching notes & 153 & 3.64 & 1.086 \\
\hline $\mathbf{3 0}$ & I use computers in teaching my lessons in the class & 153 & 2.75 & 1.067 \\
\hline $\mathbf{3 1}$ & I use computers in evaluation and measurement of students' work & 153 & 3.13 & 1.207 \\
\hline $\mathbf{3 2}$ & I use computers for administrative purposes & 149 & 3.30 & 1.256 \\
\hline $\mathbf{3 3}$ & I use the computer to browse the Internet/WWW & 152 & 3.86 & 1.010 \\
\hline $\mathbf{3 4}$ & I use the computer/internet for communication( email, chat etc.) & 155 & 4.04 & .975 \\
\hline
\end{tabular}

Teachers' Educational Technology Preferences for Preparation and Teaching Purposes The big percentage of the teachers uses the Internet and conventional books in preparing teaching notes $(28.1 \%)$. This is followed by the Internet + computer programs + conventional books $(12.4 \%)$, the internet $(7.8 \%)$, the Internet + video + conventional books (7.2\%), All (5.2\%), the Internet + scanner + computer programs + conventional books $(4.6 \%)$ and the Internet + video + computer programs + conventional books $(3.3 \%)$. The majority of the teachers make use of a combination of wide range of educational technology, as shown in Table 5, while a small percentage uses only one technology or tool (i.e. the Internet, $7.8 \%$ ).

Table: 5

The Teachers' Educational Technology Preferences for Preparation

\begin{tabular}{|c|c|c|}
\hline $\begin{array}{l}\text { Which ones do the teachers use in preparing teaching notes? } \\
\text { (might tick more than one choice) }\end{array}$ & Frequency & Percent \\
\hline Internet, Conventional Books & 43 & 28.1 \\
\hline Internet, Computer Programs, Conventional Books/Resources & 19 & 12.4 \\
\hline Internet & 12 & 7.8 \\
\hline Internet, Video, Conventional Books/Resources & 11 & 7.2 \\
\hline All & 8 & 5.2 \\
\hline Internet, Scanner, Computer Programs, Conventional Books/Resources & 7 & 4.6 \\
\hline Internet, Video, Computer Programs, Conventional Books/Resources & 5 & 3.3 \\
\hline Conventional Books/Resources & 4 & 2.6 \\
\hline $\begin{array}{l}\text { Internet, Video, CD/DVD-Rom, Computer Programs, Conventional } \\
\text { Books/Resources }\end{array}$ & 4 & 2.6 \\
\hline Internet, Computer Programs & 3 & 2.0 \\
\hline Internet, Computer Programs, CD/DVD-Rom, Conventional Books/Resources & 3 & 2.0 \\
\hline Internet, Video, Computer Programs & 3 & 2.0 \\
\hline Internet, Scanner, CD/DVD Rom, Conventional Books / Resources & 3 & 2.0 \\
\hline Computer Programs & 2 & 1.3 \\
\hline \multirow[t]{2}{*}{ Internet, Scanner, Video, Conventional Books/Resources } & 2 & 1.3 \\
\hline & & 137 \\
\hline Internet, Scanner, Video, Computer Programs, Conventional Books/Resources & 2 & 1.3 \\
\hline Internet, Scanner & 2 & 1.3 \\
\hline Internet, CD/DVD, Conventional Books/Resources & 2 & 1.3 \\
\hline Internet, CD/DVD, ComputerPrograms, Conventional Books/Resources & 2 & 1.3 \\
\hline Internet, Video, CD/DVD Rom,Conventional Books/Resources & 2 & 1.3 \\
\hline
\end{tabular}




\begin{tabular}{l|c|c}
\hline Internet, Scanner, Video, Computer Programs, CD/DVD Rom & $\mathbf{2}$ & 1.3 \\
\hline Internet, Scanner, Video & 1 & .7 \\
\hline Internet, Scanner, Video, Computer Programs & 1 & .7 \\
\hline Internet, Scanner, Video, CD/DVD Rom & 1 & .7 \\
\hline Scanner, Computer Programs, Conventional Books/Resources & 1 & .7 \\
\hline Internet, Computer Programs, CD/DVD Rom & 1 & .7 \\
\hline Computer Programs, Conventional Books/Resources & 1 & .7 \\
\hline Internet, Scanner, Computer Programs, & 1 & .7 \\
\hline
\end{tabular}

In terms of teaching purposes, the big percentage of the teachers makes use of a combination of a (computer) projector and conventional black/white board (32.2 \%). This is followed by black/white board $(24.3 \%)$, projector + video + black/white board $(\mathbf{1 7 . 1} \%)$, and a projector $(5.9 \%)$.

Table: 6

The Teachers' Educational Technology Preferences for Teaching Purposes

\begin{tabular}{|c|c|c|}
\hline $\begin{array}{l}\text { Which ones do the teachers make use of in teaching } \\
\text { their lessons? (might tick more than one choice) }\end{array}$ & Frequency & Percent \\
\hline (Computer) Projector, Conventional Black/White Board (B/W Board) & 49 & 32.2 \\
\hline B/W Board & 37 & 24.3 \\
\hline Projector, Video, B/W Board & 26 & 17.1 \\
\hline Projector & 9 & 5.9 \\
\hline Projector, Video, IWB, B/W Board & 6 & 3.9 \\
\hline Projector, Video & 4 & 2.6 \\
\hline Video, B/W Board & 2 & 1.3 \\
\hline Projector, IWB, B/W Board & 2 & 1.3 \\
\hline Overhead projector, B/W Board & 1 & .7 \\
\hline Projector, Overhead projector, Video, B/W B & 1 & .7 \\
\hline Projector, IWB & 1 & .7 \\
\hline Projector, Overhead projector, B/W Board & 1 & .7 \\
\hline Projector, Overhead Projector, Video, IWB, B/W Board & 1 & .7 \\
\hline Projector, Overhead projector, IWB, B/W Board & 1 & .7 \\
\hline Projector, Overhead projector & 1 & .7 \\
\hline Overhead Projector, Cassette Player, B/W Board & 1 & .7 \\
\hline Projector, Cassette Player, B/W Board & 1 & .7 \\
\hline Projector, Video, Cassette Player, B/W Board & 1 & .7 \\
\hline Video & 1 & .7 \\
\hline Projector, Overhead projector, Video, Cassette Player, B/W Board & 1 & .7 \\
\hline Projector, Overhead projector, Cassette Player, B/W Board & 1 & .7 \\
\hline Overhead projector, IWB, B/W Board & 1 & .7 \\
\hline Overhead projector, Video, B/W Board & 1 & .7 \\
\hline Projector, Video, IWB & 1 & .7 \\
\hline Cassette Player, B/W Board & 1 & .7 \\
\hline
\end{tabular}


The majority of the teachers use a combination of a wide range of educational technology for teaching their lessons, as shown in Table 6, while some use only one technology or tool such as black/white board $(24.3 \%)$, a projector $(5.9 \%)$ and video $(.7$ $\%)$. To investigate the issues affecting the teachers' use of educational technologies further (i.e. for preparation and teaching purposes), the teachers were also requested to answer three open-ended questions. 75 (out of 158) teachers answered the open ended questions and their answers are presented below.

Table: 7

The Factors Preventing the Teachers' Use of Educational Technology

\begin{tabular}{|c|c|}
\hline $\begin{array}{l}\text { What do the teachers think prevent them } \\
\text { using educational technology at their schools? }\end{array}$ & $\mathbf{f}$ \\
\hline Not having (efficient) pertinent digital resources & 29 \\
\hline $\begin{array}{l}\text { Not enough computer and computer } \\
\text { projectors (in classrooms/labs) }\end{array}$ & 26 \\
\hline Not having Interactive Whiteboards (IWB) & 21 \\
\hline Not enough head projectors(in classrooms/labs) & 21 \\
\hline Not having access to the Internet in classroom & 20 \\
\hline Not having pertinent software & 20 \\
\hline Lack of desktop computers in classrooms & 19 \\
\hline $\begin{array}{l}\text { Not enough educational } \\
\text { technology (i.e. video, printers) }\end{array}$ & 15 \\
\hline No/not enough ICT labs & 7 \\
\hline Shortage of power supply & 5 \\
\hline Lack of subject orientated educational technology labs & 5 \\
\hline Not enough ICT technicians to sort out ICT related technical problems & 4 \\
\hline Not having networks/servers in the classrooms/labs & 4 \\
\hline Not knowing how to use educational technology & 3 \\
\hline Out of date technology/not having right equipment & 3 \\
\hline $\begin{array}{l}\text { The use of computers for not } \\
\text { intended usage purposes }\end{array}$ & 3 \\
\hline Overcrowded classes & 2 \\
\hline Not having flexible curriculum in terms of ICT-contents to be taught & 2 \\
\hline Students' ICT level is low & 1 \\
\hline $\begin{array}{l}\text { Students do not know } \\
\text { ICT terms and concepts }\end{array}$ & 1 \\
\hline Not having a team of experts who can prepare digital resources & 1 \\
\hline
\end{tabular}


The teachers' answers to the first open-ended questions (Table 7) reveal that the teachers think that their schools do not have enough:

$>$ (efficient) pertinent digital resources,

$>$ computer and computer projectors,

$>$ IWBs,

$>$ head projectors,

$>$ access to the Internet in the classrooms, and other relevant educational technology (i.e. video, printers etc.).

All the issues emphasised in Table: 7 seem to be considered the factors that affect the teachers' use of educational technology at primary, secondary and high schools in the small town in the eastern part of Turkey.

Table: 8

The Factors Enabling the Teachers' Use of Educational Technology

What can be done to enable the teachers

use of educational technology more at their schools?

\begin{tabular}{l|c}
\hline (Static) computer and computer projectors should be available in classrooms & $\mathbf{2 8}$ \\
\hline IWB should be available in classroom and labs & $\mathbf{2 8}$ \\
\hline Providing (efficient) pertinent digital resources & $\mathbf{2 8}$ \\
\hline Access to the Internet should be available in classrooms & 15 \\
\hline Access to ICT-labs should be available for students & 13 \\
\hline More computers/ICT-labs are needed & 11 \\
\hline Efficient ICT courses regarding the use of ICT for teaching/learning should be provided & $\mathbf{9}$ \\
\hline Efficient ICT courses regarding the use of the Internet efficiently & $\mathbf{9}$ \\
\hline Giving specific computers, scanner, printer, software etc. to departments & $\mathbf{8}$ \\
\hline Teachers should be provided with laptops & $\mathbf{5}$ \\
\hline Providing ICT labs & $\mathbf{4}$ \\
\hline Efficient ICT courses regarding how to prepare digital resources & $\mathbf{4}$ \\
\hline Computer-assisted education/teaching should be encouraged & $\mathbf{3}$ \\
\hline Providing computer networks/servers in labs & $\mathbf{3}$ \\
\hline Students (and parents) should be made aware of the importance and use of ICT for & 3 \\
\hline learning & $\mathbf{3}$ \\
\hline Encouraging students to make use of ICT & $\mathbf{2}$ \\
\hline Providing distance ICT-education & 1 \\
\hline Encouraging teachers to make use of ICT & 1 \\
\hline Wireless system should be available & 1 \\
\hline
\end{tabular}


The teachers' answers to the second open-ended questions (Table: 8) reveal that providing;

$>$ static computer and computer projectors,

$>$ IWBs,

$>$ (efficient) pertinent digital resources access to the Internet in the classrooms,

$>$ access to ICT-labs for students, and the other issues emphasised in Table 8 can further enable the use of educational technology at their schools.

Table: 9

The Factors Further Enabling the Teachers' Use of Educational Technology

\begin{tabular}{l|l}
\multicolumn{1}{c|}{$\begin{array}{c}\text { Is there anything else the teachers want to add regarding } \\
\text { the use of educational technology at their schools? }\end{array}$} & $\boldsymbol{f}$ \\
\hline Pertinent digital resources should be provided & 3 \\
\hline $\begin{array}{l}\text { Efficient ICT courses regarding the use of common programs (i.e. Word, Excel, } \\
\text { PowerPoint, Photoshop, the Internet etc.) for teachers }\end{array}$ & 3 \\
\hline Efficient ICT coursed regarding the use of ICT in teaching/learning & $\mathbf{2}$ \\
\hline Providing all pertinent types of educational technology & $\mathbf{2}$ \\
\hline There has to be at least an ICT lab in every single school & $\mathbf{2}$ \\
\hline Controlled and secure use of ICT & $\mathbf{2}$ \\
\hline Increasing ICT-use awareness & $\mathbf{2}$ \\
\hline More efficient/fast technology & $\mathbf{1}$ \\
\hline
\end{tabular}

The teachers also think that providing (a) pertinent digital resources, (b) efficient ICT courses regarding the use of common programs (i.e. Word, Excel, PowerPoint, Photoshop, the Internet etc.) for teachers and the other issues mentioned in Table 9 can further enable them to make use of educational technology at primary, secondary and high schools.

Differences between their Perceptions in terms of Some Independent Variables

Analysis of variance (ANOVA) was administered to examine whether there were any differences between the teachers' computer self-efficacy perceptions (items 1-18) and frequency of computer use for certain purposes in terms of how long they have been using computers (Table 10). 
Table: 10

Analysis of Variance (ANOVA) for Computer Self-efficacy Perceptions and Frequency of Computer Use for Certain Purposes in terms of How Long the Teachers have been Using Computers

\begin{tabular}{|c|c|c|c|c|c|c|}
\hline \multicolumn{2}{|c|}{ How long have the teachers been using computers? } & \multirow{2}{*}{\begin{tabular}{c|}
$\mathbf{N}$ \\
27
\end{tabular}} & \multirow{2}{*}{$\begin{array}{c}\text { Mean } \\
2.9959\end{array}$} & \multirow{2}{*}{$\begin{array}{c}\text { Std. Dev. } \\
.49593\end{array}$} & $\mathbf{f}$ & $\mathbf{p}$ \\
\hline \multirow{4}{*}{$\begin{array}{l}\text { Computer self-efficacy } \\
\text { perceptions (items 1-18) }\end{array}$} & 1-5 years & & & & \multirow{4}{*}{8.049} & \multirow{4}{*}{$0.001 *$} \\
\hline & 6-10 years & 80 & 3.2757 & .50990 & & \\
\hline & $11-15$ years & 33 & 3.6465 & .51610 & & \\
\hline & 16 and above & 3 & 3.2407 & 1.00051 & & \\
\hline \multirow{4}{*}{$\begin{array}{l}\text { Frequency of computer use } \\
\text { for certain purposes (items } \\
29-34 \text { ) }\end{array}$} & $1-5$ years & 26 & 2.9423 & .57916 & \multirow{4}{*}{8.041} & \multirow{4}{*}{$0.001 *$} \\
\hline & 6-10 years & 80 & 3.3625 & .70849 & & \\
\hline & $11-15$ years & 31 & 3.8280 & .83720 & & \\
\hline & 16 and above & 4 & 3.9167 & .51819 & & \\
\hline
\end{tabular}

The difference between the year-groups was statistically significant in terms of computer self-efficacy perceptions score (items 1-18). The teachers who have been making use of computers for the longest period of time (i.e. 11-15 years and 16 and above) seem to have the highest computer self-efficacy perceptions scores. The shorter the period of time, the lower computer self-efficacy perceptions score they have. The teachers who have been making use of computers for the shortest period of time (i.e. 1-5 years) seem to have the lowest computer self-efficacy perceptions scores. In the same way, Analysis of Variance (ANOVA) was administered to examine whether there were any differences between how long the teachers have been using computers (items 1-18) and the teachers' frequency of computer use for certain purposes (items 29-34). The difference was statistically significant (Table: 10).

Table: 11

Analysis of Variance (ANOVA) for Computer Self-efficacy Perceptions, Frequency of Computer Use for Certain Purposes and Computer Using Level in Certain Programs in terms of Where the Teachers can Access Computers

\begin{tabular}{|c|c|c|c|c|c|c|}
\hline \multicolumn{2}{|c|}{ Where can the teachers access computers? } & $\mathbf{N}$ & Mean & Std. Deviation & f & $\mathbf{p}$ \\
\hline \multirow{3}{*}{$\begin{array}{l}\text { Computer self-efficacy perceptions } \\
\text { (items 1-18) }\end{array}$} & Home & 34 & 3.0572 & .45597 & \multirow{3}{*}{6.623} & \multirow{3}{*}{$0.002 *$} \\
\hline & School & 23 & 3.2005 & .52377 & & \\
\hline & Both & 86 & 3.4354 & .56642 & & \\
\hline \multirow{3}{*}{$\begin{array}{l}\text { Frequency of computer use for } \\
\text { certain purposes (items 29-34) }\end{array}$} & Home & 32 & 3.1094 & .54970 & \multirow{3}{*}{4.101} & \multirow{3}{*}{$0.019 *$} \\
\hline & School & 24 & 3.3056 & .91902 & & \\
\hline & Both & 85 & 3.5412 & .76199 & & \\
\hline \multirow{3}{*}{$\begin{array}{l}\text { Computer using level in certain } \\
\text { programs (items 19-28) }\end{array}$} & Home & 16 & 2.7250 & .49733 & \multirow{3}{*}{3.354} & \multirow{3}{*}{$0.042 *$} \\
\hline & School & 9 & 2.7333 & .76322 & & \\
\hline & Both & 36 & 3.2500 & .86833 & & \\
\hline
\end{tabular}

* a=0.05; differences are statistically significant 
The teachers who have been making use of computers for the longest period of time (i.e. 16 and above) seem to have the highest frequency of computer use for certain purposes scores. The teachers who have been making use of computers for the shortest period of time (i.e.1-5 years) seem to have the lowest frequency of computer use for certain purposes scores.

The teachers who have access to computers both at school and home seem to have the highest computer self-efficacy perceptions scores.

Likewise, the teachers who have access to computers both at school and home seem to have the highest frequency of computer use for certain purposes scores.

In the same way, the teachers who have access to computers both at institution and home seem to have the highest computer using level in certain programs scores.

These results mean that the more access the teachers have to computers, the higher scores they have for computer self-efficacy perceptions, frequency of computer use for certain purposes and computer using level in certain programs.

Moreover, access to computers at schools seems to be more important than having access at home.

Table: 12

Analysis of Variance (ANOVA) for Computer Self-efficacy Perceptions and Frequency of Computer Use for Certain Purposes in terms of How Often the Teachers Use Computers

\begin{tabular}{|c|c|c|c|c|c|c|}
\hline \multicolumn{2}{|c|}{ How often do the teachers use computers? } & \multirow{2}{*}{$\begin{array}{l}\mathbf{N} \\
\mathbf{1 2} \\
\end{array}$} & \multirow{2}{*}{$\begin{array}{l}\text { Mean } \\
2.7500 \\
\end{array}$} & \multirow{2}{*}{$\begin{array}{c}\text { Std. Dev. } \\
.49775 \\
\end{array}$} & \multirow{2}{*}{$\mathbf{f}$} & \multirow[t]{2}{*}{$\mathbf{p}$} \\
\hline \multirow{4}{*}{$\begin{array}{l}\text { Computer self- } \\
\text { efficacy perceptions (items 1-18) }\end{array}$} & A few hours weekly & & & & & \\
\hline & A few days weekly & 18 & 3.2778 & .51941 & \multirow{3}{*}{5.771} & \multirow{3}{*}{$0.001 *$} \\
\hline & A few hours every day & 74 & 3.2838 & .41944 & & \\
\hline & Very often every day & 38 & 3.5556 & .68797 & & \\
\hline \multirow{5}{*}{$\begin{array}{l}\text { Freq. of comp. use } \\
\text { for certain purposes (items 29-34) }\end{array}$} & No-answer & 1 & 2.0000 & . & \multirow{5}{*}{4.700} & \multirow{5}{*}{$0.001 *$} \\
\hline & A few hours weekly & 12 & 2.8333 & .36927 & & \\
\hline & A few days weekly & 18 & 3.5278 & .71686 & & \\
\hline & A few hours every day & 75 & 3.3356 & .75610 & & \\
\hline & Very often every day & 35 & 3.7190 & .76030 & & \\
\hline
\end{tabular}

* a=0.05; differences are statistically significant

The difference between how often the teachers use computers was statistically significant in terms of their computer self-efficacy perceptions score (items 1-18) and frequency of computer use for certain purposes score (items 29-34, Table 12). The teachers who use computers most often seem to have the highest computer self-efficacy perceptions scores and frequency of computer use for certain purposes score. 
In other words, the teachers who use computers least seem to have the lowest computer self-efficacy perceptions scores and frequency of computer use for certain purposes score.

\section{DISCUSSION and IMPLICATIONS}

The results of the current study match with the findings of the existing similar results in that the teachers in general have good computer self-efficacy perceptions, their level in certain programs is good and they often make use of computers for a wide range of purposes.

The teachers also think that while the lack of pertinent digital resources, computer and computer projectors, interactive white boards, head projectors and other relevant educational technology such as video and printers prevent their use of educational technology; the provision of computer and computer projectors, interactive white boards, (efficient) pertinent digital resources, access to the Internet and labs and efficient ICT courses can further enable them to make efficient use of ICT at primary, secondary and high schools (Türel 2013; Buchanan 2013; Goktas, Yildirim. \& Yildirim 2009; Usluel-Koçak and Seferoglu 2004; Akkoyunlu 2002; Yigit et al. 2002).

In terms of computer self-efficacy perceptions, the only issues about which the teachers do not seem to have good self-efficacy perceptions are (a) the use of computers to plan their time and (b) the use of computers playing a big part in their life.

These findings also match the existing findings of the similar results (Türel 2013; UsluelKoçak and Seferoglu 2004; Green 1996).

The results of the current study also reveal that computer self-efficacy and frequency of computer use for certain purposes are positively associated with higher level of educational technology use (i.e. the length of ICT use). These results match the existing findings of similar studies (Türel 2013; Buchanan 2013; Ajjan and Hartshorne 2008; Hsu and Chiu 2004; Cassidy and Eachus 1995). Since the teachers who have made use of computers for the longest period of time have the highest computer self-efficacy perceptions and computer using level in certain programs, the implications are that (a) the use of ICT should be encouraged for learning/teaching from the early years and (b) all teachers should be provided with full structural factors and efficient ICT courses from the very beginning.

Computer self-efficacy and frequency of computer use for certain purposes are also positively associated with where the teachers can access and how often the teachers use computers. Likewise, computer using level in certain programs is also positively associated with where the teachers can access computers. These results show that both individual and contextual factors play a significant part in computer self-efficacy, frequency of computer use for certain purposes and computer using level in certain programs. For that reason, the implication is to provide full access to ICT, educational technology and pertinent digital resources for teachers at primary, secondary and high schools. 
Moreover, while providing the up-to-date educational technology and efficient ICT courses is considered a positive factor in efficient use of educational technology by the teachers, the lack of structural factors (i.e. lack of pertinent hard- and software and technical support) is considered a negative factor which affects teachers' optimal use of educational technology at primary, secondary and high school.

As a result, the implication is not only to equip teachers with what they need for learning/teaching, but it is also to provide teachers with efficient ICT courses pertinent to the use of all required digital resources and programs.

It appears that the teachers at primary, secondary and high schools in the small town in the eastern part of Turkey do not have (enough) necessary educational technology and pertinent digital resources. The use of educational technology at the target schools also seems to be very limited, which is not even considered surface uses of digital technologies, as emphasized by some researchers (Kwok-Wing 2011; Rossiter 2007).

Consequently, it is not wrong to claim that the schools in the target town has been very slow in taking the fullest advantage of the potential benefits that educational technology can offer at primary, secondary and high schools.

These findings are practical recommendations not only for the schools in the target town, but also for all other schools in Turkey that have similar structural problems and do not make efficient use of educational technology at their schools. To sum up, the implications are:

$>$ to provide technical infrastructure/structural factors for both teachers and students and

$>$ to enable efficient and effective use of the pertinent educational technology for the targeted goals through providing technology plans, inservice training, technical support, role models, efficient digital resources for the targeted objectives. Most of these suggestions are also emphasized in in other studies (Türel 2013; Buchanan 2013; Goktas, Yildirim and Yildirim 2009; Usluel-Koçak and Seferoglu 2004).

\section{BIODATA and CONTACT ADDRESSES of the AUTHOR}

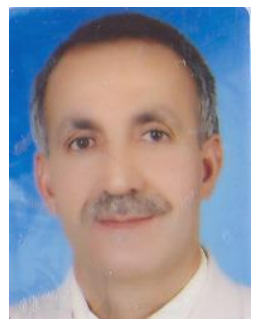

Asst. Prof. Dr. Vehbi TUREL has a First Class Degree in Teaching of English as a Foreign Language, M.Ed. in Educational Technology and TESOL, and a Ph.D. on Design of Interactive Multimedia Language (Listening) Software. He is a professional software developer and is mainly interested in teaching, research and creating CALL materials in English, Kurdish and Turkish. He has twenty six years teaching experience and has been working as a co-editor, editor-in-chief, editorial board member, author and reviewer for several refereed international journals and book publishers. He teaches and publishes internationally. 


\author{
Vehbi TUREL \\ The University of Bingol, TURKEY \\ Vocational Higher School, \\ Computer Programming \\ Phone: 04262160012 ext: 1202 \\ Email: vehbiturel@yahoo.co.uk
}

\title{
REFERENCES
}

Ajjan, H. \& Hartshorne. R. (2008). Investigating faculty decisions to adopt Web 2.0 technologies: Theory and empirical tests. The Internet and Higher Education. 11(2). 71-80.

Akkoyunlu, B. (2002). Öğretmenlerin internet kullanımı ve bu konudaki öğretmen Görüşleri [Use of Internet by teachers and their opinions on the issue]. Hacettepe Üniversitesi Eğitim Fakültesi Dergisi [Hacettepe University Journal of Education]. 22. 1-8.

Albion. P. (2001). Some factors in the development of self-efficacy beliefs for computer use among teacher education students. Journal of Technology \& Teacher Education. 9(3). 321-48.

Altun, A.; \& Çakan. M. (2006) Undergraduate students' academic achievement. Field dependent/independent cognitive styles and attitude toward computers. Educational Technology \& Society. 9(1). 289-297.

Askar, P.; \& Umay. A. (2001). İlköğretim Matematik öğretmenliği öğrencilerinin bilgisayarla ilgili öz-yeterlilik algısı [Perceived computer self-efficacy of the students in the elementary mathematics teaching programme]. Hacettepe Üniversitesi Eğitim Fakültesi Dergisi [Hacettepe University Journal of Education]. 21. 1-8.

Bandura, A. (1997). Self-efficacy: The exercise of control. New York: Freeman.

Balasubramanian, K.. Clark-Okah, W.; Daniel. J.; Fereira. F.; Kanwar. A.; Kwan. A. et.al. (2009). ICTs for higher education: Background paper from the Commonwealth of Learning. Paris: UNESCO. Available online from and Retrieved on 10 January 2014. http://unesdoc.unesco.org/images/0018/001832/183207e.pdf

Becta, (Leading Next Generation Learning). (2009). Harnessing technology for next generation learning: Children. Schools and families implementation plan 2009-2012. [Available from and retrieved on 15 January 2014.

http://webarchive.nationalarchives.gov.uk/20101102103654/http://publications.becta. org.uk/download.cfm?resID=39547

Bilge, F. (2012). Bir grup ilköğretim öğrencisinde bilgisayara yönelik bağımlılık eğilimi Değerlendirmesi [Evaluation of computer addiction tendencies in a group of primary students]. Hacettepe Üniversitesi Eğitim Fakültesi Dergisi [Hacettepe University Journal of Education]. 43. 96-105. 
Buchanan, T.; Sainter. P.; \& Saunders, G. (2013). Factors affecting faculty use of learning technologies: implications for models of technology adoption. Journal of Computing in Higher Education. 25. 1-11.

Cassidy, S.; \& Eachus. P. (2002). Developing the computer user self-efficacy (CUSE) scale Investigating the relationship between computer self-efficacy. gender and experience with computers. Journal of Educational Computing Research. 26(2). 133-53.

Duncan-Howell, J. (2012). Digital mismatch: Expectations and realities of digital competency amongst pre-service education students. Australasian Journal of Educational Technology. 28(5). 827-840. Available from and retrieved on 30 January 2014. http://www.ascilite.org.au/ajet/ajet28/duncanhowell.html

Goktas, Y.; Kucuk. S.; Aydemir, M.; Telli, E.; Arpacik, O.; Yildirim, G.; \& Reisoglu, I. (2012). Educational technology research trends in Turkey: A content Analysis of the 2000-2009 decade. Educational Sciences: Theory \& Practice. 12(1). 177-199.

Goktas, Y.; Yildirim, S.; \& Yildirim, Z. (2009). Main Barriers and Possible Enablers of ICTs Integration into Pre-service Teacher Education Programs. Educational Technology \& Society. 12(1). 193-204.

Green, K. C. (1996). Campus computing 1995: The sixth national survey of desktop computing in higher education. Encino. CA: Campus Computing

Hong, K.-S.. \& K.-W. Lai. (2011). ICT for accessible. effective and efficient higher education: Experiences of Southeast Asia. Australasian Journal of Educational Technology. 27(8). Editorial: Preface to the Special issue.

Hsu, M.-H.. \& Chiu. C.-M. (2004). Internet self-efficacy and electronic service acceptance. Decision Support Systems. 38(3). 369-381.

Keser, H. (2005). Insan bilgisayar etkileşimi ve sağlığa etkisi değerlendirmesi [Humancomputer interaction and assessment of its impact on health]. Nobel Yayınevi. Ankara.

Kennedy, G.; B. Dalgarno, S.; Bennett, K.; Gray, J.; Waycott, T.; Judd, A.; et al. (2009). Educating the net generation: $A$ handbook of findings for practice and policy. The University of Melbourne. [Available from and retrieved on 12 March 2014. http://www.netgen.unimelb.edu.au/outcomes/handbook.html

Kregor, G., Breslin, M., \& Fountain, W. (2012). Experience and beliefs of technology users at an Australian university: Keys to maximising e-learning potential. Australasian Journal of Educational Technology. 28(8). 1382-1404.

Kucuk, S.; Aydemir. M.; Yildirim, G.; Arpacik, O.; \& Goktas, Y. (2013). Educational technology research trends in Turkey from 1990 to 2011. Computers \& Education 68. 4250. 
Kwok-Wing, L. (2011). Digital technology and the culture of teaching and learning in higher education. Australasian Journal of Educational Technology. 27(8). 1263-1275.

Maher, D.; Phelps, R.; Urane, N.; \& Lee, M. (2012). Primary school teachers' use of digital resources with interactive whiteboards: The Australian context. Australasian Journal of Educational Technology. 28(1). 138-158. Available from and retrieved on 30 January 2014. http://www.ascilite.org.au/ajet/ajet28/maher.html

Lim, C. P. \& C Chai, S. (Eds). Building the ICT capacity of the next generation of teachers in Asia. Australasian Journal of Educational Technology. 28 (Special issue. 6). 949-964. Available fron and retrieved on 15 Oct. 2102 http://www.ascilite.org.au/ajet/ajet28/romeo.html

Odabası, F. (2005). Parent's views on the Internet use. TOJET. 4(1). 38-45.

Ozden, M. Y. Erturk. I; \& Sanlı, R. (2004). Students' Perceptions about online assessment: A case study. Journal of Distance Education. 19(2). 77-92.

Prensky, M. (2001). Digital natives. digital immigrants. On the Horizon. 9(5). NCB University Press. Available from and retrieved on 25 February 2014. http://http://www.marcprensky.com/writing/Prensky\%20 \%20Digital\%20Natives.\%20Digital\%20Immigrants\%20-\%20Part1.pdf

Romeo, G. I. (2006). Engage. empower. enable: Developing a shared vision for technology in education. In D. Hung \& M. S. Khine (Eds). Engaged learning with emerging technologies (pp. 149-175). Dordrecht. The Netherlands: Springer.

Romeo, G.; Lloyd, M.; \& Downes, T. (2012). Teaching Teachers for the Future (TTF): Building the ICT in education capacity of the next generation of teachers in Australia. In

Rossiter, D. (2007). Whither e-learning? Conceptions of change and innovation in higher education. Journal of Organisational Transformation and Social Change. 4(1). 93-107.

Turel, Y. K.; \& Johnson, T. E. (2012). Teachers' Belief and Use of Interactive Whiteboards for Teaching and Learning. Educational Technology \& Society. 15(1). 381-394.

Turel, V.. \& P, McKenna. (2013). Design of Language Learning Software. In Bin Zou et al. (Eds.). Computer-Assisted Foreign Language Teaching and Learning: Technological Advances (pp. 188-209). USA. Hershey: IGI-Global. Retrieved on 12 January 2014. http://www.igiglobal.com/chapter/design-language-learning-software/73265

Turel, V. (2012). Design of Feedback in Interactive Multimedia Language Learning Environments. Linguistik Online. 54(4). 35-49. Available from and retrieved on 25 Sep. 2012. http://www.linguistik-online.de/54 12/tuerel.pdf 
Turel. V. (2011). Learners' Attitudes to Repetitious Exposure in Multimedia Listening Software. EUROCALL Review. 19 (September). 57-83. Available and retrieved on 12 Oct. 2012. http://eurocall-languages.org/review/index.html

Turel, V. (2010). Advanced Turkish. ReCALL. 22(3). 396-401. Available from http://journals.cambridge.org/action/displayAbstract?fromPage =online\&aid $=7884195$ or http://cls.arizona.edu/resources/review-recall-tur3.htm Retrieved on 18 January 2014.

Turel. V. (2014). Learners' perceptions towards interactive multimedia environments. Hacettepe Üniversitesi Eğitim Fakültesi Dergisi [Hacettepe University Journal of Education]. forthcoming.

Turel, V. (2013). The use of educational technology at tertiary level. Hacettepe Üniversitesi Eğitim Fakültesi Dergisi [Hacettepe University Journal of Education]. 28(2). 482-496. Available from and retrieved on 12 February 2014. http://www.efdergi.hacettepe.edu.tr/201328-2VEHBİ\%20TÜREL.pdf.

Usluel-Koçak, Y.. \& Seferoğlu, S. S. (2004). The perceptions of academic staff members in faculties of education regarding their self-efficacy in relation to computer use. their use of IT. and their perceptions of obstacles in the use of IT. and solutions they propose for those problems (in Turkish). Educational Sciences and Practice (Eğitim Bilim/eri ve Uygulama). 6(3). pp. 143-157.

Yanpar, Y. T. (2011). Öğretim teknolojilleri ve materyal tasarımı (2. baskı) [Instructional technology and material design (2nd ed.)]. Ankara: Anı Yayıncılık.

Yeung, A. S.; K. M. Lim.. E. G. Tay.; Chiang. A. C.. \& C. Hui. (2012). Relating use of digital technology by pre-service teachers to confidence: A Singapore survey. Australasian Journal of Educational Technology. 28(8). 1317-1332.

Yigit, Y. G.. Zaim. N.. \& Yıldırım.. S. (2002). Yükseköğretimde öğretim amaçlı teknoloji kullanımı: Bir durum saptaması [The use of technology for teaching in higher education: A case study]. Eğitim ve Bilim. 27(124). 42-51. 